\title{
Ethnic Stereotypes in Traditional Communication as a Framework of Ukrainian World View
}

\author{
Olha Mazurkevich, Yuriy Osiyskiy, Liudmyla Suprun, Nadiia Skrypnyk, Iuliia Lebed, Valentyna \\ Tymkova
}

\begin{abstract}
Two-dimensionality of the Ukrainian mentality as a combination of two types of mentality-agricultural (peasant) and Cossack - has established the fundamental principles of organization of the Ukrainian society as based on internal mechanisms of self-organization. The events of the late eighteenth century, such as destruction of the Zaporizhian Sich, liquidation of remnants of the autonomous system of Ukraine and the Cossacks as the lead social group, introduction of serfdom, implementation of Russian laws in the territory of "Russian" Ukraine, etc., had a negative impact on the balanced two-dimensional ethnic mentality, rendering it features of introversiveness. This manifested itself in the intensification of internal life due to external activity, dominance of the humanistic component - morality, goodwill, aestheticism.
\end{abstract}

\section{INTRODUCTION}

Dominant components of the Ukrainian mentality were defined in close connection with nature, which is perceived as the life-giving mother, in the predominance of the emotional and aesthetic over rational and logical, in cordocentrism ("philosophy of the heart"), individualism, aesthetism, priority of the feminine, which resulted in softness, lyricism, etc. All these features are adequately reflected in the sphere of communication, giving a unique flavor and specific features to household etiquette of Ukrainians, which distinguish it from the etiquette of neighboring nations. These distinctive features predetermine various manifestations of tolerance, goodwill, reverence and hospitality.

Ethnic stereotypes, symbols and standards that define the identity of the ethnic group are formed, preserved and evolved in the sphere of communication. The content of stereotypes of ethnic communication is manifested through a system of signs, which includes verbal formulas, gestures,

Revised Version Manuscript Received on October 15, 2019.

Olha Mazurkevich, Vinnytsia institute of Open International University of Human Development "Ukraine", Vinnytsia, Ukraine, (Email: olgamazyrkevich@gmail.com)

Yuriy Osiyskiy, Vinnytsia institute of Open International University of Human Development "Ukraine", Vinnytsia, Ukraine, (Email: osijskij77@gmail.com)

Liudmyla Suprun, South Ukrainian National Pedagogical University named after K. Ushynsky, Odessa, Ukraine, (Email: lvsuprun@ukr.net)

Nadiia Skrypnyk, Communal Institution of Higher Education "Vinnytsia Humanities and Pedagogical College, Vinnytsia, Ukraine, (Email: nadiyvnua@gmail.com)

Iuliia Lebed, Communal Institution of Higher Education "Vinnytsia Humanities and Pedagogical College, Vinnytsia, Ukraine, (Email: iulialebed@gmail.com)

Valentyna Tymkova, Vinnytsia National Agrarian University, Vinnytsia, Ukraine, (Email: tymkova_v@ukr.net) facial expressions, plastic body positions (poses), kisses, use of objects that are given a symbolic meaning, rules of behavior in certain situations. The set of traditional symbols used is extremely wide, and their use eliminates the need for explanations.

Ethnic stereotypes of behavior, manifesting themselves through the signification, make a coding system different for specific peoples, play an important role of ethnic identifiers and inter-ethnic dividers. The basis of ritual and etiquette behavior is the symbolic sign and action language. Other codes - the verbal and substantive - supplement (are adjusted to) this ritual action code. Predominance of visual means of communication is characteristic of traditional cultures Secondary meaning of verbal texts is already evidenced by the fact that certain rituals and etiquette situations only envisage silence.

Along with facial expressions, poses and other expressive movements of a man, etiquette gesture is an essential layer of ethnic culture. Difference between an etiquette ethnic gesture and an ordinary movement is that it has a symbolic character. Ritual and etiquette gesture always have a communicative focus - they are addressed to a particular person, the highest essence, etc. Hand gestures play an important role in communicative behavior, the symbolism of which reflects the ancient archaic ideas. Physical contact is important in communicative behavior: a touch is a way of transmitting both positive and negative impacts.

Ethnic culture of Ukrainians, which in the XIX - early XX century appeared as a holistic, dynamic, self-regulating system, has played a crucial role in the preservation of the ethnic group. In conditions of stateless existence, when the policy of dominant empires was aimed at denationalization of Ukrainians, inhibiting the growth of national consciousness, it was the ethnic culture that had become an important national integration factor that stimulated the processes of national identity. As noted by H. Skrypnyk, its influence was significantly increased by self-organizing hidden factors that "served the national integration function" [16, p. 241]. These hidden psychological factors conceptualized in the above historical period as a phenomenon of people's soul, that is, the deep psychological identity of the ethnic group that subsequently began to define the concept of "mentality" [16, p. 241].
Published By: Eyes Intelligence Engineering \& Sciences Publication 
Given the importance of the factor of mentality in studying ethnic traditions of communication, it is necessary to clarify the meaning of the term "mentality". As noted by modern researchers, in particular, H. Skrypnyk, unambiguous and generally accepted interpretation of this multi-faceted concept that has an extremely wide substantial range has not yet been developed in the humanitaristics [16, p. 241-242]. In the XIX century, it was used in the definition of such concepts as "the people's spirit", "the people's soul", and nowadays the substantive field of the term "mentality" is mostly interpreted as "a kind of mindset and world-view of a particular people", "national psycho-structure", "psycho-behavioral archetypes of a community," etc. [16, p. 242].

The complexity and ambiguity of the "mentality" concept is also noted by O. Strazhnyi - the author of "Ukrainian Mentality. Illusions. Myths. Reality». "Mentality is a concept that is difficult to understand. It can be hardly rationally interpreted, - says the researcher... "It is something that is felt but not realized. However, it includes generally accepted rules and customs, and traditions, and language and world-view" [17, p. 4]. O. Strazhnyi still tries to interpret the "mentality" concept as a whole. In his opinion, it is "a certain set of values, habits, not always realized coordinate system, psychological algorithms that form the view of a person or a group of people on the surrounding reality and, consequently, determine the person's behavior" [17, p. 4].

Another definition is proposed by L. Matvieieva, who interprets "mentality"(from the Latin mentalis - "mental", "spiritual") as a perception of the world, the world-view; mindset, way of thinking of a person or a social group; deep psychological level of individual or collective consciousness...", as well as "a set of psychological and behavioral attitudes of an individual or a social group" [14, p. 494]. The mentality of an ethnic group is formed and evolves in the course of its historical development under the influence of the environment, social institutions and traditions, integrating value forms of consciousness, such as religion, morality, philosophy, with the world of unconscious mental states. The mentality, therefore, determines a holistic way of life of a person and a people [14, p. 494].

Formation of "more or less single type of the Ukrainian mentality" which, having a traditional basis, absorbed all variety of regional distinctions and time layers, occurred, according to a number of researchers, since the middle of the XVII century. It is when, says Ponomariov, national consciousness was gradually replacing the regional one, which is evidenced by extensive use in the specified period of the ethnonym "Ukrainians" and ethnopolitonym "Ukraine" [15, p. 1161].

The traditional basis of the Ukrainian mentality appeared in the agricultural essence, which determined the corresponding - agricultural - type of national character. A key concept of the traditional basis of ethnic culture, according to M. Hrymych, was the concept of "the earth" and "the cult of the earth"; that of the ethnic mentality was magical thinking, and that of the national character was caution, prudence, carefulness [7, pp. 34-36]. The researcher also points out that the ancient traditional basis for ethnic culture was subsequently overlaid by a powerful layer of the Cossack culture, forming a type of mentality and a peculiar

type of the national characterdifferent from agricultural. The traditional type of agricultural mentality was based on the idea of settlement, attachment to the land and home, its main value was the bread, the main origin was the woman, the mother, the image of which included the mythological essence of the Mother Earth, the Foremother. Different from the agricultural was the type of Cossack mentality: it was based on the idea of the road, the value of the male principle, rather than settlement [8, pp. 27-30].

Two-dimensionality of the Ukrainian mentality as a perception of agricultural and Cossack mentality has established the fundamental principles of organization of the Ukrainian society as based on internal mechanisms of self-organization. "That is why, - says Ponomariov, - the systems of family relationship, nepotism, sworn brotherhood, sworn sisterhood, community, guild organizations, etc., have acquired perfect development therein. Such orientation of the system with appropriate communication of ethnic stereotypes characterizes the Ukrainian society as a stable, able to withstand external changes" [15, p. 1163].

The events of the late XVIII century, in particular, destruction of the ZaporizhianSich, liquidation of remnants of the autonomous system of Ukraine and the Cossacks as the lead social group, implementation of Russian laws in the territory of "Russian" Ukraine, etc., had a negative impact on the balanced two-dimensional ethnic mentality. Restriction of national and social rights, enslavement of the peasantry, absence of any legal mechanisms to protect human and national dignity, systemic anti-Ukrainian measures of assimilatory and unifying nature, all these negative political, historical and social legal transformations of the Ukrainian society of the late XVII-XIX century resulted in re-emphasis of ethno-psychological, philosophical and moral-ethical qualities of the Ukrainian community: military instructions and courage, the bearers of which the Cossacks were, mainly born from rural environment, lost to the introduction of pasivism in public life, reconciliation with the national oppression and social bondage" [11, p. 250]. Ukrainian mentality of that time mainly appears as introversion.

Describing the concept of "introversion", psychologist Ya. Yarema, in particular, notes that it is "...the return of the subject to himself, to the world of inner experiences. The subjective world takes precedence over the world of objects... Attention is mainly focused on the facts and problems of an internal nature... Thought has a tendency to attract objective factors to the requirements of the idea or to ignore them. The objective is subjectivized. The inner life develops more intensively due to the outward activity" [18, p. 41]. Mentality introversiveness is reflected in the predominance of the humanistic component - morality, kindness, tolerance, aesthetics, philosophical attitude to life [17, p. 251].

Dominant components of the Ukrainian mentality are the close connection with nature, which is perceived as the life-giving mother; predominance of the emotional and aesthetic over rational and logical, cordocentrism ("philosophy of the heart"), individualism, aesthetism, priority of the feminine, which resulted in softness, lyricism, 
etc. All these features are adequately reflected in the sphere of communication, giving a unique flavor to the household etiquette of Ukrainians.

The mentality of Ukrainians to a certain extent differs from that of neighboring nations, in particular Russians, as $\mathrm{M}$. Kostomarov noted in his work "Two Russian Nationalities". Thus, describing the ethnopsychology of Ukrainians, the scientist pointed to such constitutive features as democracy, tolerance of strangers, religious tolerance, and no desire to subordinate and assimilate other nations. According to $\mathrm{M}$. Kostomarov, the Ukrainian society as a voluntary association of people on democratic principles, in which everyone has the right to vote, fundamentally differs from the Russian community or "world", which is "like an abstract expression of someone else's will", which absorbs an individual. In the XIX - early XX century, ideals of public life also differed: a federal structure for the Ukrainians split between various states and the ideal of empire for the Russians [18, pp. 32-80].

Modern Russian culture researcher B. Yegorov cites four factors that had, in his opinion, the greatest "mental influence" on the Russians: "Orthodox religion, serfdom, huge monarchical state-empire and peasants" [10, p. 52]. The researcher, in particular, argues that the ethnic mentality of the Russians was significantly determined by the Orthodox-Byzantine Church principles: "First of all...- the unconditional rightness of only one position, one idea, one church. The true church is one; everything else is hostile, alien..." [10, p. 52]. Consequently, the high life had a dominating principle: "... either domestic or foreign. Foreign religions, foreign nations, foreign clothes...", that is, the principle of hostility, rather than tolerance to everything foreign, was dominating [10, p. 52-53]. Community-based lifestyle, strictly regulated and strengthened by the rules of the Orthodox Church, gave rise to the idea of the superiority of the whole - the general over the individual. Imperialism played a special role in the mentality of the Russians. Until the mid-twentieth century, the territory of Russia continuously expanded due to the capture of the territories of neighboring peoples, which could not but form characteristic features of the people's mentality". There is not a single voice, not a single note of protest about the wars of conquest in the national consciousness, in the folk art, $-\mathrm{B}$. Yegorov notes... - the mass popular consciousness wasn't going to assume a position of the won nations even for a second, there was just a look from the part of Russia" [10, p. 63].

Ethnic stereotypes, symbols and standards that define the identity of the ethnic group are formed, preserved and evolved in the sphere of communication. The content of stereotypes of ethnic communication is manifested through a system of signs, which includes verbal formulas, gestures, facial expressions, plastic body positions, kisses, use of objects that are given a symbolic meaning, rules of behavior in certain situations. The set of traditional symbols used is extremely wide, and their use eliminates the need to explain, in particular, in such crucial moments of people's life as courtship, matchmaking, conclusion of trade and other agreements. Thus, a Ukrainian girl would traditionally show her disagreement to marry by giving a pumpkin or a pestle to the man who aspires to her hand. Obtaining a pumpkin or "licking the pestle", the man requires no further explanation.

Ethnic behavioral stereotypes, manifested through signs, make up a different system of coding for specific peoples. "... Even such purely physiological phenomena as sexual intercourse or cough in different ethnic environments are different, - emphasizes A. Ponomariov. - Especially noticeable are ethnic differences in how people dress, how they eat, welcome each other, say goodbye, thank each other, get acquainted, how they gesticulate, what their facial expressions are..." [15, p. 1164].

It is predominance of visual means of communication that is characteristic of traditional cultures. The basis for ritual behavior is the language of significant symbols of gestures and actions. Other codes - the verbal and substantive - are adjusted to this ritual action code. Secondary meaning of verbal texts is already evidenced by the fact that certain rituals and etiquette situations only envisage silence. Thus, verbal texts in archaic rituals often came down to only exclamations - calls for the deity.

The most significant information of key importance for the whole society is transmitted in the ritual through the language of signs, poses, facial expressions, special handling of things [6, p. 25]. A gesture, which along with facial expressions, poses and other expressive movements of a man is an essential layer of ethnic culture, plays an important role in the etiquette. Difference between an ethnic gesture and an ordinary movement is that it has a symbolic character. It is only when a certain movement is given a symbolic meaning that it acquires the status of a gesture. Ritual and etiquette gesture always have a communicative focus - they are addressed to a particular person (when greeting or saying good-bye), the highest essence, etc.

One of the oldest gestures recorded in iconography is the gesture of adoration (prayer), when both hands are extended toward the God or the object of worship. In Christian iconography, TheotokosOranta was depicted with hands raised in prayer, in particular, in the altar part of St. Sophia Cathedral, Kyiv. However, the origins of this gesture are pre-Christian; therefore, starting from the XIII-IX centuries, the image of Oranta in Christian iconography was replaced by the image of the Theotokos with her arms open in front of her chest. As N. Kondakov says, "With this gesture, the Christian art strongly separated from the ancient heritage of gestures in art, whereas Byzantium created the image of the Theotokos and hearty feeling that subsequently resulted in the development of religious spiritual movements" [4, p. 357]. The gesture of adoration, however, is preserved in the folk art: women's higher nature - Mother Earth or Berehynia is still depicted on Ukrainian embroidered towels with her hands raised.

Hand gestures play an important role in communicative behavior, the symbolism of which reflects ancient archaic ideas. Thus, the archaic nature is rendered to a hand sign as a symbol of power, high social status that was realized in the so-called great gestures and respective verbal formulas: "Everything is in God's hands", "Under a high hand" (prince, chieftain, etc.), "My right hand" (about a critical employee). Nickname of the old Russian Prince Dolgoruky had a negative connotation and meant that his interests had spread

Blue Eyes Intelligence Engineering

$\&$ Sciences Publication 
to the neighboring land, symbolized "grabbiness". Known expression "Your hand is short..." means that a person referred to is not capable of fulfilling promised actions, etc. Gesture (wave) of the hand can be a greeting and farewell. A strong long-lasting male handshake is a manifestation of goodwill, whereas a short weak handshake, especially when one of the partners tries to pull his hand out of the hand of the second one, has the opposite meaning and is unmistakably recognized as a manifestation of malevolent, negative attitude.

Gestures of the right and left hands have the meaning of polar symbols, since the "right" is traditionally associated with "truth", "rightness", something right, and the "left" with "untruth", "wrong", "falsehood"; that is the "right - left" opposition has not only spatial, but also moral and ethical meaning, and the right side is traditionally has a positive meaning, whereas the left - a negative one. Guests of honor were seated to the right of the host. In many cultures of the world, the male principle is traditionally associated with the right side, the female - with the left. "The association of the male principle with the right side, life, day, sun is not due to the fact that these qualities are objectively closer to men rather than women, but due to the fact that they belong to the same classification row, - says I. Kon. - Another thing is that such associations, transformed from the symbols into the normative reference points of thinking, affect the behavior and psyche of people" [12, p. 90].

In ancient times, the order of placing a woman to the left of a man, characteristic of all Slavic peoples, also existed in Ukraine. However, in the XVII century, due to historical peculiarities of its development, this order changed, identifying certain changes in gender relations. These changes have occurred for both unmarried youth and families. Thus, symbolizing respect for the woman-mother, the hostess was placed to the right of her man at a festive table. Most often girls would walk to the right of guys. Thus, the archaic balance of seats changed as gender relations became democratized. This process began in Ukraine relatively early, proceeded slowly and gradually, which resulted in multivariate etiquette situations for positioning men and women, unmarried women, girls. Thus, an unmarried woman would mostly occupy a place to the right of a man, whereas the wife would traditionally occupy a place to the left, which, however, was not strictly fixed - in young couples, a wife most often occupied an unconventional right place. "It is a common situation in Ukraine when a bride is led down the aisle from the right, whereas after the wedding, it is the man who takes his traditional right place" [15, p. 1180]. The exception was the Dnieper region in the XIX early XX century, where archaic etiquette situation preserved with a man walking ahead of a woman, which symbolized the prestige of the male principle and subordination of a woman [1].

In etiquette communication, distance between the partners is of great importance as well. In the mythological sense, this distance is a space the boundaries of which cannot be violated without good reason. It is different in various nations, being a "complex factor of etiquette standards of communication and, to a certain extent, an indicator of national character" [15, p. 1176]. Special studies, the results of which are cited by $\mathrm{P}$. Kheidmets in "Spatial regulation of human communication", show that the distance between communicating people is up to $70 \mathrm{~cm}$ for the Mediterranean peoples, 100-120 cm for the peoples of the Caucasus and 122-366 cm for the Americans [18, p. 72-84]. Interpreting these values, the researcher points out that "a large distance between partners speaks of minimization of physical contact - handshakes, hugs, kisses, pats, as well as a minimum of gestures. At the same time, a large distance provides a large number of avoidances of those various contacts that show a friendly attitude to family members, etc. In the Ukrainian environment, the physical distance during communication fluctuates within $70-100 \mathrm{~cm}$, which, according to A. Ponomariov, can testify to sufficient liberation of moral and ethical standards and, at the same time, great liberty of choice between standard and individual behavior. The researcher also draws attention to the multiplicity of regional models of etiquette behavior, which also confirms its relative freedom [15, pp. 1176-1177].

Physical contact is important in a human behavior: a touch is a way of transmitting both positive and negative impacts. According to a traditional belief, a touch can heal or transmit negative energy, disease, which led to both strict regulation of physical contact, especially with strangers, and their ritualization. In the traditional culture of many peoples, a handshake between men and women was prohibited. The spread of this taboo is associated with the idea that a sexual appeal can be conveyed through a handshake. For Eastern Slavs, a handshake between a guy and a girl could mean an affectionate gesture. Thus, in the Ukrainian traditional culture, a guy would only get the right to hold the girl's hand after he had declared himself, after the official engagement (hence the name of the ceremony - engagement). In the XIX century, in the vast Belarusian traditional culture, this gesture even had a special name: "They (a guy and a girl - authors' note) shake hands in an inconspicuous way, - said $\mathrm{M}$. Dovnar-Zapolskyi in his "Notes on the Belarusian Ethnography," - and this handshake called "handout" is equivalent to love declaration" [9, p. 290].

In Ukrainian walk-arounds, touch of hands was not forbidden. Thus, during Kupala (Midsummer) games "... guys and girls group together so that each boy takes the hand of "his" girl, stand in a circle around the fire, follow the sun and sing Midsummer songs" [3, p. 437]. During the Midsummer games, guys and girls jumped in pairs over the fire. Describing these and other youth games, S. Kylymnyk emphasizes that a guy would only take the hand of "his" girl, so this gesture symbolized the manifestation of affection and mutual sympathy [3, p. 439]. Despite the severity of traditional stereotypes of segregation of genders, that is, avoiding the demonstration of gestures of intimacy, in terms of social and economic development, they have transformed. Thus, quite early, already in the XVII - XVIII centuries, in the Ukrainian folk dance, guys could take the girls hands, touch shoulders, waist, couple dances became more popular unlike in the ethnic environment of earlier periods [15, p. 1174]. 
In etiquette handshake, there are several significant aspects, namely: shaking hands with a person of the opposite sex, who first shakes the hand - an older or younger, all present should shake hands. The emotional coloring and the technique of this gesture are also important [6, p. 33]. In traditional Ukrainian culture of the XIX - early XX century, a handshake was mostly characteristic of men. The first to give the hand was senior by age or social status. People avoided shaking hands with little-known people, as well as with those in constant communication.

A handshake signified completion of a trade deal and was common during fairs. "Striking hands" had the same meaning - it seemed to legitimate the inviolability of the deal.

Wedding ceremonies began in Ukraine with striking hands, which had the force of law. Thus, In Chernihiv, "settling an affair", the parents of the young couple "stroke hands" and prayed together [13, p. 71]. In the Ukrainian wedding ceremony, the hands of the young couple were joined over a loaf, which meant "oath on bread", which in agricultural peoples was considered holy and confirmed the inviolability of marriage. In the Russian wedding tradition, the ritual nature of the handshake also was emphasized by the fact that the hand was shaken across the table over a loaf. Thus, in Yaroslavl province, a matchmaker passed the loaf through the hands of the young couple's parents three times, then broke it and gave each father a piece of it [2, p. 218]. After a handshake or a hand strike, which had the sacred meaning of an oath, the decision could not be reconsidered.

The handshake retained a sacred symbolic meaning in ritual situations (wedding, etc.), at the same time existing in everyday etiquette relations. Transition of handshakes from the sphere of sacred gestures to the practice of everyday communication meant, on the one hand, raising the status of etiquette communication, a certain sacralization of everyday relations between people, and, on the other hand, the extension of democratic principles in the sphere of communication because the handshake is a "gesture of peers" [6, p. 40].

The significance of this gesture was enhanced if it was performed with two hands, although it could be done with one. Thus, a bride would offer a towel with two hands; when meeting important guests, bread would be served on a towel using two hands. Two hands would be used to break bread in ritual situations, although in everyday situations it was just cut. The hand of a particularly reputable man would be shaken with two hands.

Two-hand gestures could show different emotional states. Thus, among Ukrainian women, "hit it by hands on the floor" could mean either surprise, or confusion, or despair, or joy. Clapping hands could have the same broad semantics: this gesture was used in the Slavic tradition both as a manifestation of joy at the good news and the manifestation of grief at the news of misfortune, death, etc.

Etiquette kiss arose on the basis of a ritual one, absorbing its mythological semantics to a certain extent. Ritual and etiquette kisses are emphatically asexual in nature as opposed to affectionate kiss. They are used in a wide range of situations - from communicative situations related to confirming the kinship - marriage, nepotism, fraternization, sworn sisterhood, etc., to kissing during meetings, farewells.

Greeting kiss on the lips, typical for Ukrainians, is a manifestation of goodwill, friendly unity. Greeting kissing in Ukraine had different ways: a kiss on the lips was a sign of special affection; on the cheek - a manifestation of usual friendliness. Piety kissing had different semantics as well: a kiss on the hand meant a high degree of respect; kissing the head, shoulder, feet was a sign of submission. In Ukraine, there was a habitual kissing of hands to senior people. This was done with special reverence. According to Polish ethnographer E. Rulikowski, when a peasant child wanted to kiss the hand of parents or anyone of older people, it took the hand with its two hands and kissed it on the top [5, p. 126]. Kissing of hands and feet was known in ancient times among European peoples, however, in the late middle ages its use was narrowed and only restricted to kissing the hands of priests and women.

\section{CONCLUSIONS}

Behavioral stereotypes that formed through centuries of selection, in a generalized form reflect the mentality of Ukrainians, characteristic features of which are introversion, individualism, a sense of the closest connection with nature, the dominance of the humanistic component - morality, benevolence. Etiquette is a direct manifestation and form of ritualization of moral values. In the traditional culture of the nineteenth and early twentieth century Ukrainians to a great extent, it kept in touch with its sources - mythological perceptions, religion, rites and rituals that had a distinct ethno-national and regional specificity. Ethnic stereotypes of etiquette communication played the role of ethnic identifiers in the defined period, defining "Ukrainskii typ povedynki" (A. Ponomarev), peculiarity of national character and way of life.

\section{REFERENCES}

1. Viddil rukopysnykhf ondiv IMFE - F. 14-5, od. zb. 397, ark. 31,68

2. Helmold. Slavianskaiakhronyka / Helmold. - M.: Nauka, 1963. - S. 185.

3. Kylymnyk S. Ukrainskyirik u narodnykhzvychaiakh $\mathrm{v}$ istory chnomu osvitlenni / S. Kylymnyk. - Kn. 2. - K.: Oberehy, 1994. - $528 \mathrm{~s}$.

4. Kondakov N.P. Ykonohrafyia Bohomatery / N.P Kondakov. - $\quad$ SPb., 1915. - T. 2. - S. 357.

5. Rulikowski E. Zapiskietnograficzne z Ukrainy // Zbiorwia domoscido antropologii Kragoweg. - Krakow, 1879. - T. 3. - Dz. 3. - S. 126

6. Balushok V. Svitserednovichchia v obriadovosti ukrainskykht sekhovykh remisnykiv / V. Balushok. - K. Nauk. dumka, 1993. - $118 \mathrm{~s}$.

7. Hrymych M. Narodna kultura ukraintsiv yak dzerkalo ukrainskoho natsionalnoho kharakteru // Etnichna samosvidomist i natsionalna kultura: Tezydopovidei. K., 1991. - S. 34-36.

8. Davydiuk V. Pervisna mifolohiia ukrainskoho folkloru: 3-e vyd., dopovn. I pererodl. / V. Davydiuk. - Lutsk: Volynskaknysha, 2007. - 320 s.

9. Dovnar-Zapolskyi N. Zametky po belorusskoi etnohrafyy // Zhyvaiastaryna. - 1893. - Vyp. 2. - S. 290. 
10. Ehorov B. Ocherky po ystoryy russkoikultury XIX veka // B. Ehorov. Yzystoryy russkoi kultury. T. U / KhIKhvek /. - M.: Yzd-vo «Iazuky russkoi kulturb», 2000. - S. 13-392.

11. Kaloev B.A. Osetyny: Ystoryko-etnohrafycheskoe yssledovanye / B.A. Kaloev. - M.: Nauka, 1971. - S. 195.

12. Kon Y.S. Vvedenye v seksolohiiu / Y.S. Kon. - M.: Nauka, 1988. - S. 90.

13. Lytvynova-Bartosh P. Vesilniobriady i zvychai Chernihivshchyny // Materialydo ukrainsko-ruskoi etnolohii. - Lviv, 1906. - T. 3. - S. 71.

14. Matveeva N. Solntsevorot: praznyky, obychay, predanyia / N. Matveeva, - K.: Ukr. Tsentr dukhovnoi kultury, 1995. $-240 \mathrm{~s}$

15. Ponomarov A.P. Tradytsiino-pobutova kultura: Pobutovyietyket // Istoriia ukrainskoi kultury: U piatytomakh. - T. 3. - K.: Nauk. dumka, 2003. - S. 1161-1181.

16. Kon Y.S. Vvedenye v seksolohiiu / Y.S. Kon. - 16 Skrypnyk H.A. Natsionalna mentalnist ta tradytsii ni svitohliadni uiavlennia // Istoriia ukrainskoi kultury: U piatytomakh. - T. 4. - Kn. 1 / Peredm. H.A. Skrypnyk. S. 239-262.

17. Strazhyi O.S. UkraiSnskyi mentalitet: Iliuzii. Mify. Realnist. / O.S. Strazhyi. - K.: «Knyha», 2008. - 368 s.

18. Kheidmets P.S. Prostranstvennai arehuliatsiia obshchenyia cheloveka // Trudy po psykholohy. - Tartu, 1977. - Vyp. 6. - S. 72-84.

19. Iarema Ya. Ukrainska pedahohichna dumka Halychyny v imenakh / Ya. Yarema. - Lviv, 2003. - S. 41, 101-102. 